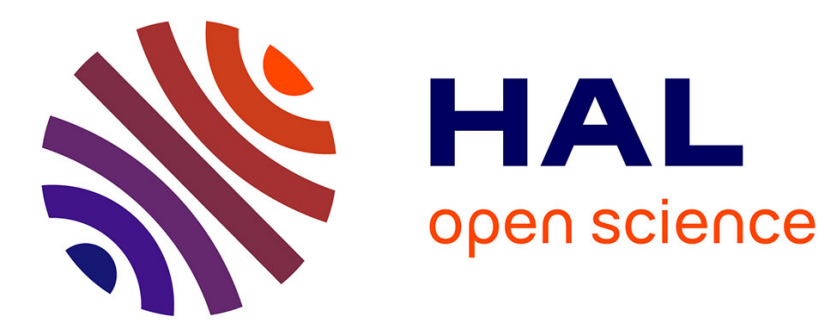

\title{
Pharmaceutical Particle Technology
}

Chuan-Yu Wu, Abderrahim Michrafy, Aleksander Mendyk, Satoru Watano

\section{To cite this version:}

Chuan-Yu Wu, Abderrahim Michrafy, Aleksander Mendyk, Satoru Watano. Pharmaceutical Particle

Technology. Powder Technology, 2015, 285 (SI), p. 1. 10.1016/j.powtec.2015.09.014 . hal-01611003

\section{HAL Id: hal-01611003 \\ https://hal.science/hal-01611003}

Submitted on 24 Jul 2018

HAL is a multi-disciplinary open access archive for the deposit and dissemination of scientific research documents, whether they are published or not. The documents may come from teaching and research institutions in France or abroad, or from public or private research centers.
L'archive ouverte pluridisciplinaire HAL, est destinée au dépôt et à la diffusion de documents scientifiques de niveau recherche, publiés ou non, émanant des établissements d'enseignement et de recherche français ou étrangers, des laboratoires publics ou privés. 
Editorial

\section{Pharmaceutical Particle Technology}

Over $80 \%$ of pharmaceutical products are in the solid dosage form, which are manufactured using particles and generally involve a series of unit operations, including crystallization; mixing/blending; granulation; drying; milling; coating; compaction; packing and transporting. Thus, targeted formulation of powder blends with optimal performance in these manufacturing processes, and controlled handling and processing of pharmaceutical particles are critical to safeguard the product quality and to reduce the cost associated with manufacture of pharmaceutical products. It has been estimated that it could save up to US\$ 90 billion per year by improving the manufacturing process in the pharmaceutical industry worldwide. Such ideas of knowledge based, rational pharmaceutical product development are also endorsed by pharmaceutical regulatory agencies, e.g. FDA, and their Process Analytical Technology (PAT) initiative.

To achieve this, the pharmaceutical manufacturing processes need to be better understood so that they can be optimised, properly controlled and scaled up. In addition, the formulations need to be well designed and characterised so that those with targeted attributes can be formulated to improve the quality and functionality of the products. It hence requires concerted action from different disciplines, including chemistry, pharmacy, materials science and process engineering. Over the last two decades, instead of the conventional empirical formulation practice, there has been an increasing effort in developing and manufacturing pharmaceutical products using an engineering approach which is based on a better scientific understanding of particulate behaviours in the process. This has been facilitated by advances in formulation and manufacturing technologies, measurement and characterisation techniques, and modelling and simulations.
This special issue on pharmaceutical particle technology aims at showcasing recent advances in the development of science based processing and manufacturing processes for producing high quality pharmaceutical products. It contains 18 research papers, which are selected from the contributions to "Particulate Processes in the Pharmaceutical Industry IV", an international conference held in Potsdam, Germany on 14-18th September 2014, as well as invited papers from the active research groups worldwide. These papers cover a wide range of topics related to pharmaceutical particle technology such as formulation engineering, characterisation, process understanding, modelling and simulations.

We would like to acknowledge all authors and reviewers for their contribution, support and cooperation. We also wish to thank the Elsevier Editorial team for their support in publishing this special issue.

Chuan-Yu Wu University of Surrey, UK

Abderrahim Michrafy CNRS, Ecole des Mines, Albi, France

Aleksander Mendyk Jagiellonian University - Medical College, Cracow, Poland

Satoru Watano Osaka Prefecture University, Japan 